Jurnal Ilmial

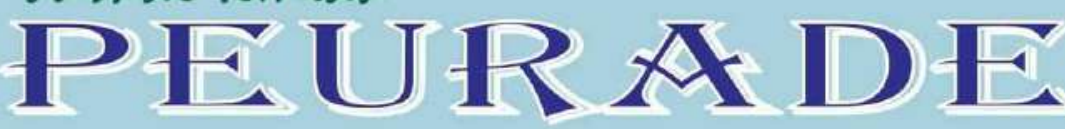

Vol. 5, No. 1, January 2017

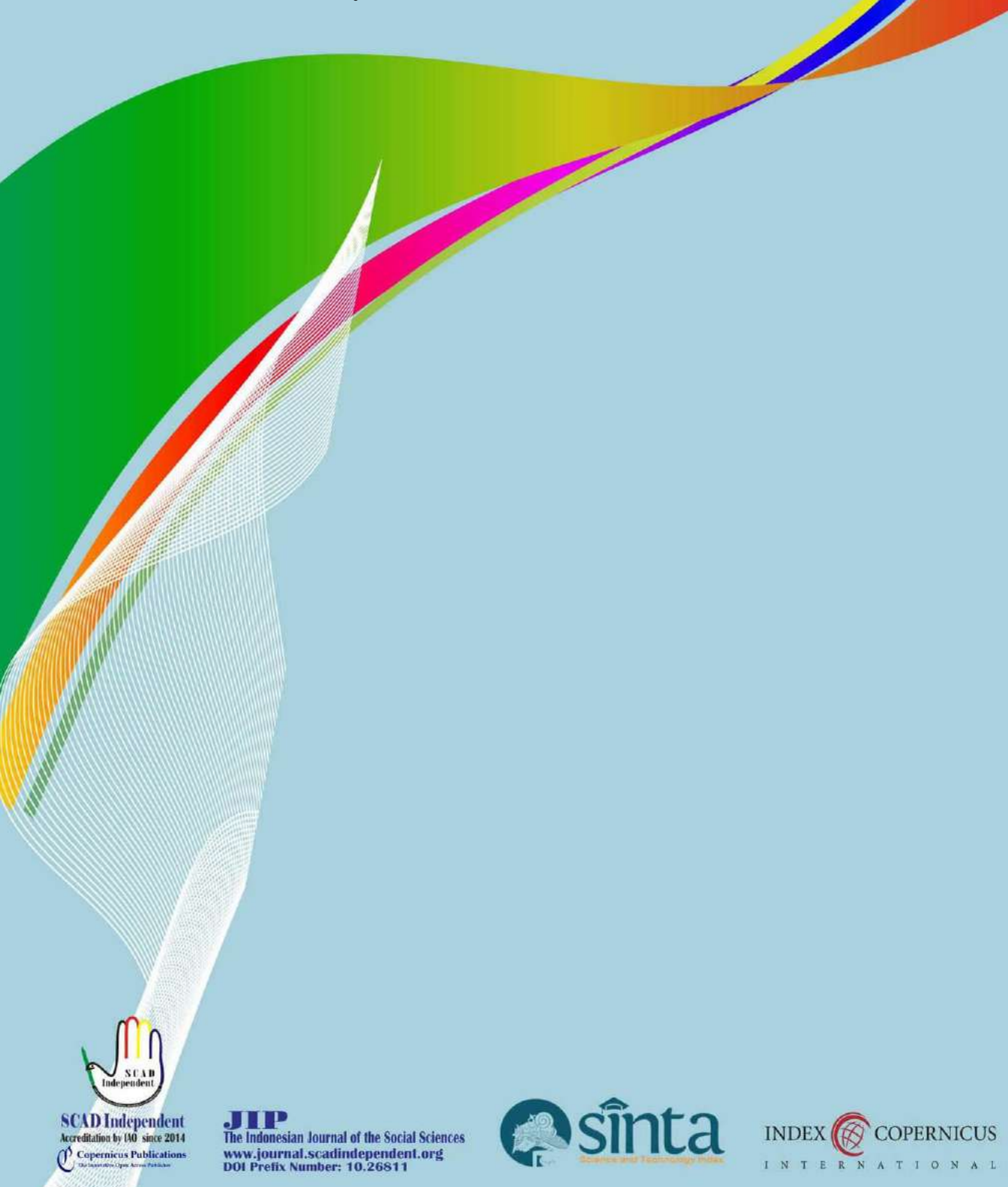




\title{
IMPLEMENTING THE TEACHING SUPERVISION BY PRINCIPALS IN IMPROVING THE PERFORMANCE OF TEACHERS IN ACEH BESAR
}

\author{
Said Ashlan \\ Education Management Department, State University of Medan, Indonesia \\ Contibutor Email: ashlansaid44@gmail.com
}

Received: Aug 20, 2016

Accepted: Sept 2, 2016

Published: Jan 28, 2017

Article Url: http://journal.scadindependent.org/index.php/jipeuradeun/article/view/116

\begin{abstract}
Teaching supervision by principal in Aceh Besar State High Schools (especially in Excellent Senior High School 2 of Ali Hasjmy and Senior High School 1 Baitussalam) is one of factors to improve the quality of professional teacher performance. The purpose of this study was to identify the activities, techniques, implementations, supporting and inhibiting factors in teaching supervision by principals in improving teacher performance. The subjects of this research were principals, vice principals, and teachers. This study used qualitative approach and descriptive method. Meanwhile, the inhibiting factors of teaching supervision were the principals had other activities outside the school and did not have adequate time for the supervision, principal's demonstration technique was still conventional, there was lack of fund, and there were teachers who were not creative and some of them were susceptible to illness (age factor).
\end{abstract}

Keywords: Teaching Supervision, Teacher Performance, Senior High School 


\section{A. Introduction}

Build education is an effort that will never stop as long as humans have a hope for a better quality of life for the survival of civilization. This is certainly something that is logical, ethical and aesthetic values will strengthen in the context of our life on earth. All parties, both political stakeholders, social, economic, military, etc. especially related to education actually have their respective roles in the context of systemic, and definitely would contribute significantly. Whether realized or not the quality of education development, education philosophically that it is a process that leads to the quality of life of the wise man according to competence in their respective communities.

According to the Law on National Education System of the Republic of Indonesia concerning teacher No. 20 of 2003 Article 39 paragraph (1) and (2) states: "The power of education in charge of carrying out the administration, management, development, monitoring, and technical services to support the educational process in the educational unit. Educators are professionals in charge of planning and carrying out the process of learning, assessing learning outcomes, coaching and training, and conduct research and community service, particularly for educators at universities".

Judging from the findings in the field that there is a teacher for reasons of employment opportunities in the education sector more easily and more fundamental reasons. Then the teacher performance appraisal needs to be done. Dharma (2008: 20) stated "The performance standard seed to be formulated to be used as a reference in conducting assessments, comparing what is with what is expected". This is in accordance with the Regulation of the Minister of National Education No. 13 of 2007 on a standard school / Madrasah. In these regulations, supervisory education units are required to have a competency is academic supervision / instruction to teachers using approaches and techniques appropriate supervision.

Supervision of teaching by the head teacher is one of the principal tasks in developing teachers through monitoring functions. Supervision is done by principals at its core is to provide guidance, assistance to solve the problems facing education including teachers and not find fault with the 
teacher.Teachers who have a good perception of supervision of teaching the teachers to teach well. The results of the identification problem of teaching supervision by the head of Senior High Schools in Aceh Besar (especially in Excellent Senior High School 2 of Ali Hasjmy and Senior High School 1 of Baitussalam) carried out by the beginning of the study in general observations are: (1) The supervision by the principal has not contributed significant impact on teacher performance, (2) Schedule of implementation supervision by principals have organized and programmed, (3) Technical supervision conducted principals influence teacher performance is not optimal. Supervision should be implemented and the principal has a positive impact greatly affects the performance of teachers.

\section{B. Method}

This research used a qualitative approach using descriptive methods. Data obtained from respondents are used as they are. Moleong (2006: 6) defines "Qualitative research is research that aims to understand the phenomenon of what is experienced by the study subjects such as behavior, perception, motivation, action, etc., in a holistic manner and descriptions in the form of words and language, the specific context in which nature and by utilizing various methods of nature". The place of research was conducted at Excellent Senior High School 2 of Ali Hasjmy and Senior High School 1 of Baitussalam of Aceh Besar. According Arikunto (2010:172), "Sources of the data in the study is the subject of where the data can be obtained. When the researchers used questionnaires or interviews to collect data, then the data sources or informants called the respondent, that is, those who respond or answer the research questions, both written and oral questions".

Data collection in this study conducted by researchers through direct observation, interviews, and documentation. The degree of confidence (credibility) as the process of obtaining accurate data in accordance with the facts the truth, so there is no bias in interpreting the data source information. Researchers trying to communicate to the data, source so that data is more reliable truth. Data collection can not be separated from the triangulation technique is an integral part of various other stages. Moleong (2006: 330) 
defines "Triangulation is a technique that utilizes the data validity checking something else and triangulation with the means to compare and check the sources behind the degree of confidence in the information obtained through time and different tools in qualitative Research".

\section{Research Finding}

Based on the research that has been done then the researchers examine the discussion of results, as follows:

\section{Supervision Activities of Teaching by the Head teacher in Improving Teacher Performance}

In the framework of the implementation of the capacity building program which is the principal mandate of Presidential Decree No. 1 of 2010, the Head of Human Resource Development Education and Education Quality Assurance Agency has developed training materials for capacity building principals. The development of the material has been referred to the standard school/Madrasah as stipulated in Decree No. 13 Year 2007 on Standards for School/Madrasah.

Supervision of teaching performance of teachers by principals is a process of the competent guidance to teachers and other school personnel who directly handle the learning process of the students, to improve teaching and learning situation, so that students can learn effectively to the achievement learning is increasing. The role of the teacher and the principal task proposed by Saud (2009: 36) there are several categories, namely: "(1) teacher as a teacher, (2) Teachers as teachers and educators, and (3) Teachers as teachers, educators, and also agents' renewal and community development". Principals suggested Deliberation Subject Teacher (DST) teachers to be active in order to increase knowledge, and try to assign teachers to teach in accordance with the scientific field owned by each. Supervision carried out continuously, so that the problems faced by teachers can look for a way out, and ultimately teachers can develop the potential towards more professional. 
2. Supervise the implementation techniques used teaching principals in improving teacher performance, including:

a. With individual talks directly to teachers 'ability to select potentially good or not, especially in solving problems related to teachers' personal and learning with simulation as a way to increase the performance of teachers, demonstrations of learning undertaken by the principal, so that teachers can analyze the observed performance as self introspection, although there really is not the best way of teaching. This activity is carried out by the principal in a programmed manner.

b. Group techniques, among others: to hold a meeting or meetings (meetings), and held a discussion group (group discussions). According to Mukhtar, et al (2009: 57) discussion groups: “A group of activities in face-to-face situation, exchange of information, or to decide a decision on a particular issue".

The role of the school principal as a supervisor has been established with the aim tailored to prevent the irregularities and the teachers did not do more careful in carrying out his job.

\section{The factors supporting and inhibiting the implementation of the} supervision of the principal in improving teacher performance

The school principal has executed properly supervised teaching but is still limited to managing the completeness of the teachers' teaching and calling the teacher approached the less carry out their duties and responsibilities well. In a group discussion when the principal is absent then appoint a senior teacher to lead it. Furthermore, one of the barriers experienced by the principal because there are less motivated teachers in the teaching techniques of the old (monotone) that still apply the lecture in class, so the teacher much saturated trend in teaching so that teaching can not fix a varied pattern, impressed still mediocre.

\section{Discussion}

The main activities of supervision is to provide guidance to schools in general and teachers in particular, in order to increase the quality of learning, 
of course, can also improve student achievement, and it is meant to improve the quality of graduates. If the teaching supervision carried out by the principal, then he should be able to perform a variety of monitoring and control to improve the performance of educational personnel.

\section{Teaching Principles of Supervision}

According Purwanto (2009: 117-118) for a variety of measures of supervision as well as possible, as the principal supervisor shall observe the principles of supervision, among others: 1) Supervision should be constructive and creative, 2) supervision should be based on professional relationships, not on the basis of personal relationships, and 3) Supervision should also be preventive, corrective, and cooperative.

\section{Implementation Techniques of Teaching Supervision}

Purwanto (2009:120-122) argues "Broadly speaking, the way of supervision or techniques can be classified into two, namely the individual techniques and the group techniques". This can be explained below:

a. Individual techniques, supervision is carried out individually. Activities that can be done include: Conduct classroom visits (classroom visitation), and conduct classroom observation visits (classroom observation visits). Pidarta (2009: 88) said the purpose of supervision of classroom observation techniques is "To know the overall ways to educate teachers and teaching, including teaching and personal style, and to investigate the response of the class or the students".

b. Group techniques, was conducted in group supervision. Activities that can be done include: Hold a meeting or meetings (meetings), and Hold discussion groups (group discussions). According to Mukhtar, et al (2009:57) discussion groups: “A group of activities in face-to-face situation, exchange of information, or to decide a decision on a particular issue".

\section{Teaching Supervision destination}

In connection with the purpose of supervising teachers, Sahertian (2008: 19) argues that: "The purpose of teaching is to provide supervision 
and assistance to improve the quality of teaching and teachers in the classroom, which in turn to improve the quality of student learning, not only improve teaching skills but also for the development of potential teacher quality". The purpose of teaching supervision by the principal to the teachers is essential to help teachers understand the needs and problems faced by students, in order to help students optimally.

\section{Principal and Teacher Competencies}

Based on the Law of the Republic of Indonesia Number 14 Year 2005 on Teachers and Lecturers, explains that: "Competence is a set of knowledge, skills, and behaviors that must be owned, lived, and controlled by the teacher or lecturer in performing professionalism. Teacher competence is a combination of personal ability, scientific, technological, social, and spiritual kaffah form competency standards of the teaching profession, including mastery of the material, the understanding of learners, educational learning, personal development and professionalism". Competencies associated with the principal, and in the Regulation of Ministry of National Education No. 13 Year 2007 on Standards for School/ Madrasah assert that "A head of school/ Madrasah must have dimensions of personality, managerial, entrepreneurial, supervision, and social. During this dimension of competence has not been implemented in an optimal supervision by principals various levels. With regard to the principal competency standards (supervisor) then that becomes the substance of this research will be discussed on the dimensions of teaching supervision by the principal (supervisor) separately.

\section{The role and functions of the Teachers}

Regulation of Ministry of National Education No. 16 year 2007, concerning the qualification standard of teaching/ academic and teacher competence. There are four basic competencies of teachers, namely: 1) pedagogical, 2) personal competence, 3) social competence, and 4) professional competence. With regard to teachers, Mulyasa (2009: 19-22) describes that "Teachers are educators, role and function of teachers affect the implementation of education in schools, among others: 1) As an educator and teacher, 2) As a member of the community, 3) As a leader, 4) As an 
administrator, and 5) As a manager of learning. Furthermore, the following described that effective teachers and competent professionals has the following characteristics: 1) Have the ability to create a climate conducive to learning, 2) the ability to develop strategies and learning management, 3) Have the ability to provide feedback (feedback) and reinforcement (reinforcement), and 4) has the ability to self-improvement.

\section{Role as Principal Supervisor}

Implementation of teaching supervision by the principal in terms of monitoring and control is programmed and directed appropriate goals set to improve teacher performance. Pidarta (2009: 47-48) explains that: "The authority of the supervisor according to his craft, there are two kinds, namely 1) the general supervisor is the general principals and supervisors who are experts in education and teaching in general, and 2) the supervisor is a supervisor who is an expert specialist in each field of study, some placed in offices of education".

Both of the above kinds of supervisor of special concern among education actors ever experienced development and change according to the era. Governance institutions are governed by prescribed rules, integrated procedures, perform detailed scientific and research, and tailored to the potential of the region and the development of technologies that can be acceptable to all parties by education providers in their respective environments. Furthermore, Herabudin (2009: 213) describes as a supervisor, principal doing concrete steps, such as a minimum: 1) Develop plans and policies together, 2) Involve the whole participatory teachers and school staff, 3) Conducting the decision making on the basis of deliberations consensus with all his subordinates, and 4) Observe the work program and implementation of the work program in accordance with the prowess of his subordinates, as well as to provide guidance personnel and teachers working groups.

\section{Teacher Performance}

Conceptually, Related to the performance of teachers that have been described above, there are at least six tasks and responsibilities of 
teachers in developing the profession, Saud (2009: 32-34) identified, the following: 1) The teacher served as a teacher, 2) Teachers serve as mentors, 3) The teacher served as class administrator, 4) Teachers serve as curriculum developers, teacher in charge of professional development, and 5) Teachers assigned to build relationships with the community. Duties and responsibilities of having a very close relationship with the performance, each other and the compound binds to a particular activity, especially from the aspect of education carried out by the teacher.

Measuring the performance of individuals or organizations usually used as a reference normative performance standards. As for the size/ performance indicators described Dharma (2008: 20) divided into five areas: 1) Quality of work is the quality of the work, 2) Promptness is punctuality finish the job, 3) Initiative as an initiative in completing the work, 4) Capability is the ability to complete the work, and 5) Communications is the ability to foster collaboration with other parties. The above performance standards need to be formulated to be used as reference in conducting assessments, comparing what is achieved with what was expected. Performance standards are the benchmarks for comparing the performance achieved. Job satisfaction regarding the compatibility between one's expectations in return provided. Performance standards can be used as a benchmark to hold accountability for what has been done.

\section{Developing Teacher Resource Management through Teaching Supervision}

Improvement efforts in the field of education are a must to be implemented on a continuous basis in order not to fall behind by advances in science and technology is developing so fast. Resource Teacher (ST) in schools is a central factor in education. Because of that, each school who want to advance an absolute must consider factors management strong teacher resources, as well as manage it optimally. The meaning of empowerment by Murniati, AR (2008: 48-49) is "There is an awareness or intention to deliver, transfer, or assign a task, power, authority, or the authority to others. The goal is to empower or make the individual or institution empowered to use or exploit the full potential so that it can more effectively and efficiently". 
Then from that Resource Teacher utilization can not be separated from the ability of teachers to manage the management education itself, therefore according Cut Zahri (2009: 26) "Management education is a management application in the field of education. Through education management will be able to bear reliable quality human resources". Implementation of teacher resources can be implemented with the help of a supervisor, that person or agency conducting the supervision of the teacher. The nearest help in the implementation of supervision at the school is the principal teaching especially in supervision.

\section{E. Conclusion}

1. Teaching supervision activities carried out by the head of the school in the past year is not maximized because the principal is very busy with the activities / affairs outside school.

2. Techniques of teaching supervision conducted by the principal is held group discussions, class visits, and individual talks and held simulated learning.

3. Factors chance of implementing teaching supervision by the principal, namely (a) the principal leadership to motivate, activate, and the welfare of teachers, (b) To cooperate with teachers in implementing learning programs, and (c) the existence of consciousness and spirit teachers to improve motivation in teaching. One of the principal limiting factors is the lack of implementing teaching supervisory skills of school principals in terms of availability to carry out the supervision itself, and there is no technical demonstration of renewable teaching.

\section{Bibliography}

Arikunto, Suharsimi. (2010). Prosedur Penelitian: Suatu Pendekatan Praktik. Jakarta: PT. Rineka Cipta.

Bakar, A., \& Anwar, A. (2015). Learning Materials in Character Education. Jurnal Ilmiah Peuradeun, 3(3), 405-416.

Dharma, Surya. (2008). Manajemen Kinerja. Jakarta: Kementerian Pendidikan Nasional dan Kebudayaan. 
Herabudin. (2009). Administrasi dan Supervisi Pendidikan. Bandung: Pustaka Setia.

Kaylene, P., \& Rosone, T. L. (2016). Multicultural Perspective on the Motivation of Students in Teaching Physical Education. Jurnal Ilmiah Peuradeun, 4(1), 115-126.

Moleong, Lexy J (2006). Metodologi Penelitian Kualitatif. Bandung: Remaja Rosdakarya.

Mukhtar, et al. (2009). Orientasi Baru Supervisi Pendidikan. Jakarta: Gaung Persada Press.

Mulyasa, E. (2009). Menjadi Guru Profesional Menciptakan Pembelajaran Kreatif dan Menyenangkan. Bandung: PT. Remaja Rosdakarya.

Murniati, AR. (2008). Manajemen Strategik: Peran Kepala Sekolah dalam Pemberdayaan. Bandung: Citapustaka Media Perintis.

Patimah, S. (2015). Pengaruh Rekrutmen dan Seleksi Terhadap Kinerja Kepala Madrasah Ibtidaiyah Negeri (MIN) Sekota Bandar Lampung. Jurnal Ilmiah Peuradeun, 3(1), 165-190.

Permendiknas No. 13 Year 2007 on Standards for School/Madrasah.

Permendiknas No. 16 Year 2007 on the Standards and Competencies Academic Qualifications Master.

Pidarta, Made. (2009). Supervisi Pendidikan Konstektual. Jakarta: Rineka Cipta.

Purwanto, Ngalim. (2009). Administrasi Pendidikan dan Pengawasan. Revised Edition. Bandung: Remaja Rosdakarya.

Sahertian, Piet A. (2008). Konsep Dasar dan Teknik Supervisi Pendidikan (dalam Rangka Pengembangan Sumber Daya Manusia). Jakarta: PT. Rineka Cipta.

Saifullah. (2015). The Internalization of Democratic Values into Education and Their Relevance to Islamic Education Development (Synthetic, Analytic, and Eclectic Implementation of John Dewey's Thoughts). Advanced Science Letters, Journal of Computational and Theoretical Nanoscience, 21 (7), pp. 2301-2304, DOI: 10.1166/asl.2015.6257

Sarboini, S. (2016). Performance of Employees and Impact on Promotion of Position. Jurnal Ilmiah Peuradeun, 4(1), 103-114.

Saud, Syaefudin. (2009). Pengembangan Profesi Guru. Bandung: Alfabeta. 
Sulaiman, S. (2015). Classroom Management and the Implications to Quality of Learning. Jurnal Ilmiah Peuradeun, 3(3), 431-440.

Tabrani. ZA \& Masbur, M. (2016). Islamic Perspectives on the Existence of Soul and Its Influence in Human Learning (A Philosophical Analysis of the Classical and Modern Learning Theories). Jurnal Edukasi: Jurnal Bimbingan Konseling, 1(2), 99-112.

Tabrani. ZA. (2014). Isu-Isu Kritis dalam Pendidikan Islam. Jurnal Ilmiah Islam Futura, 13(2), 250-270

Usman, M. (2015). Teaching Model of Learning English Writing at University. Jurnal Ilmiah Peuradeun, 3(3), 441-450.

Usman, Nasir. (2012). Manajemen Peningkatan Mutu Kinerja Guru: Konsep, Teori dan Model. Bandung: Citapustaka Media Perintis.

Warul Walidin, A. K., Saifullah, S. A., \& ZA, T. (2015). Metodologi Penelitian Kualitatif \& Grounded Theory. Banda Aceh: FTK Ar-Raniry Press.

Zahri, Cut. (2009). Manajemen Sumber Daya Pendidikan. Banda Aceh: Pena Persada. 